\title{
CONTAMINATED GENERATIVITY: HOLOCAUST SURVIVORS AND THEIR CHILDREN IN GERMANY
}

\section{Kurt Grünberg}

\author{
Translation by Nadja Rosental
}

Did nobody wonder where so many children's shoes came from?

Primo Levi

\begin{abstract}
This paper addresses the trauma transfer from survivors of the Shoah to the Second Generation in Germany. What does it mean for both generations to beget children after Auschwitz? This necessarily entails perceiving non-Jewish Germans and their way of dealing with history. Survivors cannot live without their memory, nor is it possible for them to conceive of a life unencumbered by this constant "contaminant". It is not possible to integrate the persecution experiences. On the contrary, decades after liberation, dissociated elements of traumatic memories penetrate everyday experiences, thought, affect and imagination as contaminants. Occasionally, these fragments of persecution experiences, like "encapsulated memories" hidden in crypts suddenly break open and frighten the survivors themselves and even more so the people around them.
\end{abstract}

KEY WORDS: trauma; transmission of trauma; Holocaust; second generation; memory.

DOI:10.1057/palgrave.ajp.3350005

After his liberation from the Auschwitz concentration camp, Primo Levi agonized over how those Germans who were not directly involved dealt with their knowledge about the persecution of the Jews. Is it really possible, as so many maintained and often still do to this day, that they did "not know" anything about "all that"? In one of his "Briefe an Deutsche" (letters to Germans), he wrote, "that I myself after liberation, in Katowice, found parcels and parcels of forms that were used to authorize German family men to pick up adults' and children's clothes and shoes from the storage

Kurt Grünberg, Ph.D., psychoanalyst (IPA), licensed psychologist, staff research member at Sigmund-Freud-Institut and research director of Jewish Psychotherapeutic Counseling Center in Frankfurt/Main (Germany).

Address correspondence to Kurt Grünberg, Ph.D., Sigmund-Freud-Institut, Myliusstr. 20, D-60323 Frankfurt am Main, Germany; e-mail: SFI-K.Gruenberg@t-online.de 
rooms in Auschwitz for free. Did nobody wonder where so many children's shoes came from?" (Levi, 1988, p. 184; transl. by N.R.).

This seemingly straightforward question not only touches upon a central aspect of Nazi crimes, but Levi's question also draws our attention to a point that is of fundamental significance with regard to the trans-generational transfer of the traumatic experiences of survivors to their descendents, because the systematic and large-scale murder of children impacts the people most profoundly. The murder of more than one and a half million Jewish children reveals that the Germans intended to annihilate the Jewish people in Europe. The genocide committed on the Jewish people using a hydrogen cyanide compound for pest control (sic!) was not intended to eliminate people who were persecuted because of unpopular views they may have held or because of their actions; rather, they were killed, gassed and-as if that was not "enough"-burnt in crematories and thus murdered, so to speak, a second time, they were extinguished from the face of the earth because they were Jews. And Jews did not belong in this world.

It is often only in times of crisis and insecurity that people realize that one day they will have to die. Who does not dream of immortality? Does this dream not come closest to being fulfilled when a new life is created? The desire to have children who themselves one day will be parents and, decades later, grandparents and great-grandparents serves the fundamental human need to live on in the other, to continue one's own life and thus the unconscious need to live forever and to escape the topic of death-at least under ordinary circumstances.

For survivors of the Shoah, this issue presents itself in a different way. Because they were forced to deal with murder and annihilation, this dramatically and irrecoverably led to a contamination of generativity (i.e. their capacity to generate). Initially, during the selection processes, only those who were able to work ("die Arbeitsfähigen") were kept alive-around 10-15\% from each "transport" — while children and the weak, pregnant women, the sick and the old "went into the gas" straight away. Many Jews were forced to look on powerlessly as their children were murdered. A 90-year-old survivor woman recently explained to me: "I have seen how little children were thrown out of balconies. I have seen how children were taken at their little feet and smashed to death against walls. I have experienced that Hitler destroyed my younger brothers and sisters. After 1945 I was scared to have children of my own".

Psychoanalyst Isidor Kaminer tells a "story" about a Jewish woman in a Polish ghetto who was carrying her crying baby in her arms. When an SS man with a friendly voice offered to calm the child down, she very hesitantly passed the child to him. The SS man then smashed the baby's little 
head on the curb (Kaminer, 2006). Who could ever imagine what it means not to be able to protect your own children in any way? ${ }^{1}$

Against this background, it is hardly surprising that Auschwitz survivor Imre Kertész in his novel Kaddisch für ein nicht geborenes Kind (Kaddish for a child not born; Kertész, 1997) has his protagonist B. respond with an abrupt "No!" to the apparently innocent question of whether he has children. This issue puts him into great distress. In his moving monologue, which is in parts reminiscent of Paul Celan's Death Fugue, B. transcends the threat of his own life: not only does he choose not to have any children, but he also turns what he suffered passively into an active-albeit suicidal! attitude and speaks of a "quite aware self-liquidation, one of the first cuts with a spade to the grave, which I myself - and that is certain now - cut into the clouds" (Kertész, 1997, p. 23; transl. by N.R., author's own emphasis).

The decision of survivors to have no children is to be understood on two levels: the one being closer to consciousness stands for the fact that these survivors want to avoid giving the Nazis a second chance to murder their children. Considering the deeper unconscious level, this is the attempt to actively "get over" the traumatic experience of the passive, helpless subjection. This, in fact, reveals the real tragic of this conflict: "getting over" a trauma normally means healing, whereas in this case, it finally expresses self-destruction.

Here, the existential confrontation emerges with Theodor W. Adorno's much-cited passage: "Cultural criticism finds itself faced with the final stage of the dialectic of culture and barbarism. To write poetry after Auschwitz is barbaric" (Adorno, 1997a, p. 30). In Jenseits von Schuld und Sühne (Beyond guilt and atonement), Jean Améry (1980) talks of the "humiliation of annihilation," of the "collapsed trust in the world," which "cannot be retrieved." "Whoever was subject to torture," says Améry (1980, p. 73), "cannot be at home again in the world". Having children after Auschwitz seemed barely conceivable.

Thus, there were those survivors of the Shoah with no or few own children born after persecution-and this paper mainly deals with this group of victims and with Second Generation Jews who are confronted with this issue. However, it was likewise characteristic of people who experienced persecution and escaped the genocide after liberation in the camps (!) for "displaced persons" to have so many children that they registered the highest birth rate of all Jewish communities worldwide. These Jews were still alive, they wanted to live again. Is there a more convincing proof of life than begetting children? This proves to be true, even if numerous survivors decided to name their children after murdered relatives.

In any case, the survivors of the Shoah faced the task of finding ways and opportunities to piece together a broken world, having experienced 
an unimaginable break with civilization, and using what had remained of their human strength and capacity for Eros and desire (cf. Kaminer, 2006; Edvardson, 1989).

But still, these survivors also dealt with the question of whether there could or should be Jewish children in post-National Socialist Germany. Is it even possible_-especially in the "country of the perpetrators" — for Jewish children to live safe lives? Would children perhaps be more protected if they weren't Jewish? After this crime against humanity committed by the Germans and a world that let it happen, is it even possible to conceive of an unencumbered, joyful life, a true life after Auschwitz? Or perhaps, on the contrary, should one-more than ever-live properly, get married, have children and grandchildren?

These are the kinds of questions considered by the descendants of the victims, who may conceive of their own existence as a replacement for their murdered relatives, brothers and sisters or children of their survivorparents. In a particular way, these children are involved in their parents' persecution, which they themselves never had to experience. Without ever having been there, Auschwitz has become their own place of origin, to which they have to refer, whether they want to or not. According to Israeli psychoanalyst Yossi Hadar, the Second Generation was "born into the Holocaust" (Hadar, 1991, p. 163).

In this paper, I would like to shed light on the trauma transfer from the First to the Second Generation by asking the question of how children of survivors view the topic of having children of their own, especially with regard to their life in Germany. This necessarily means having to deal with non-Jewish Germans, engaging with the discourse about the consequences of National Socialism on the side of the perpetrators, such as German-Jewish relations after the Shoah. The way non-Jewish Germans deal with their history is of central interest from a Jewish perspective, not least because the perception of this engagement forms the basis of how safe Jews feel in that country.

Former President of the Central Council of Jews in Germany, Ignatz Bubis, a Holocaust survivor whose life's work was connected to his wish to be accepted by the Germans as a "real German", may be understood as an example of this issue (cf. Grünberg, 2006a, p. 50 ff). While in the context of this effort, Bubis called his autobiographical book (Bubis, 1993) I am a German Citizen of the Jewish Faith, a couple of years later (a few months prior to his death), he stated with great disappointment: "But, no, I have achieved almost nothing at all. The majority [of the non-Jewish Germans, K.G.] did not even grasp what I found important. We have remained strangers to each other" (Bubis, 1999, p. 58). He continued: "Everybody in Germany feels responsible for Schiller, for Goethe and for 
Beethoven, but nobody does so for Himmler. A great many people think as Martin Walser does" (ibid, p. 58 et seqq.). What Bubis here refers to in Germany was called the "Walser-Bubis-debate" (cf. Schirrmacher, 1999). The prominent German writer, Martin Walser, gave a speech when he accepted Germany's highest literary award. On this occasion, Walser spoke of the "Holocaust Industry"; Auschwitz should not become a "routine threat, a tool of intimidation, a moral cudgel, or just a compulsory exercise" (Cohen, 1998), nor should the Germans' shame be exploited for current political purposes. Bubis, one of the honorary guests in the audience was shocked about what he heard, while the great majority of the others celebrated Walser with "standing ovations", Bubis expressed his boundless disappointment in deciding to be buried not in Germany, but in Israel.

Some of the examples to follow are based on my own empirical investigation Love after Auschwitz-The Second Generation in Germany (Grünberg, 2006a), a non-clinical study that examines the legacy of the National Socialist extermination of Jews. It not only deals with the Jewish Lebenswelt in Germany, but also with Second Generation love relationships with non-Jewish Germans, whose parents had been "on the other side". This present paper also includes clinical experiences in my work with survivors and their descendants. In order to preserve the anonymity of these people, I shall present fragments that provide deeper insight into the problems without revealing individual identities.

\section{MEMORY AND DISSOCIATION}

The fragmentary nature of these "scenes" serves an additional purpose. This way of presenting the psycho-social consequences of the Shoah points to the "way of dealing with" extreme trauma using dissociative processes. In the clinical context, the term dissociation refers to a pathological disintegration of the "unity of conscious experience, remembering and controlled action" (Leuschner, 2004, p. 60). Exceptional mental states are "characterized by states of consciousness that are separated off, partial memories, self-fragments, inadequate affect-related behavior" (ibid, 2004, p. 60). Dissociative processes, that is, the dissolution of the unity and coherence of memories, are not, however, limited to such clinical, pathological states; they also play an important role in everyday perceptions such as dreaming and are of significance in the context of traumatic experiences. It is essential to realize, however, that it is not the processing of the trauma that is pathological, but rather that the persecution itself is fundamentally inhuman and destructive.

Dissociations, that is, fragmented memory traces, unconsciously merge to form re-associations. Different layers of meaning are touched and new 
meanings are generated. Memories are fundamental to people's unmistakable identity. We are always subject to innumerable sense impressions, and we must always make sure that our own emotions and fantasies can be integrated into a coherent whole, in order for us to become one with ourselves and with our own history.

We access not only our own experiences and personal memories, but also collective imaginations, socially acquired knowledge, a people's history and culture and the surrounding society. In this context, Friedrich-Wilhelm Eickhoff cites Sigmund Freud, who asked how indispensable the phylogenetic factor is in considering "unavoidable courage", and taking on "traces of memories of the experiences of former generations" (Eickhoff, 2004, p. 448). "Knowledge" that has been stored over generations constantly interferes with current perceptions, and memories are not to be understood as photographic representations of a once experienced objective reality (although, of course, they must by no means be misunderstood as arbitrary); rather, they keep forming afresh and are subject to certain processes of decay as well as of reconstruction, for example, dramatization, downplaying or embellishment. Re-associations and whatever is connected to them are used to create new content without being able to give up their connection to memory traces.

\section{MEMORY FRAGMENTS OF SURVIVORS}

The humiliation of having been made a victim and robbed of human dignity, agonising memories of degradation, excruciating fear, discrimination, persecution and deportation, memories of being witness to such events - from the murder of individuals to mass murder-and forced participation in the perverse system of NS camps, all these experiences and memories that return as flashbacks cannot be integrated into the personality of human beings; they necessarily remain alien. Survivors have to be able to deal with the fact that ultimately their suffering is incurable, because the constant confrontation with the trauma-be it consciously as a memory or as unconscious encroaching of dissociated memory fragments-inescapably shapes their lives after survival. Persecution has become a determining characteristic of the survivors. At the same time they are plagued by the need to "shake off" this incomprehensible part of their own identity. They cannot live without their memory, nor is it possible to conceive of a life unencumbered by this constant "contaminant". It is not possible to integrate the persecution experiences. On the contrary, decades after liberation, dissociated elements of traumatic memories penetrate everyday experiences, thought, affect and imagination as contaminants. Occasionally, these fragments of persecution experiences, like "encapsulated memories" hidden 
in crypts, suddenly break open and frighten the survivors themselves and even more so the people around them. The latter does not just include their sons and daughters, who have learnt from early childhood to decipher their parents' facial expressions and gestures, and their unconscious messages. Without being aware of it, the Second Generation knows that this supposed silence of their parents is actually the medium through which they communicate their experiences, albeit in a mostly non-verbal way (Grünberg, 1997, 2004). In what follows, I shall cite a number of examples from my clinical practice that illustrate these points.

Mr. P. is a survivor who suffers from many different fears. He is married to a non-Jewish woman. He sees his Second-Generation Jewish analyst as a son, whose presence is calming to him. After his sessions, he always feels better. In the same way as my patient unconsciously considers me as his unborn son, I in turn, talk with him in a way I mostly couldn't handle with my father, who died two and a half years ago. About having been treated by non-Jewish therapists, he often says: "What would I tell them"? Even if they wanted to, they could not understand. Even his wife knows "only a little" about his persecution experiences. His once large family was almost entirely extinguished. Especially during the holidays, he has to deal with not having any relatives around him. He cries when he thinks about losing his mother, who-as he had never previously expressed-had not turned around to him when he left her at the deportation square. After liberation, he was completely isolated. Ever since, his wife has provided enormous support for him. She also makes sure that he arrives for our sessions on time. Mr. P. does not talk about the fact that his marriage has remained childless. He does, however, talk about his arrest and being taken to different concentration camps. A group of children discovered him with a number of others in their hiding place. "Jews, Jews!" these children had shouted, he said,- "and then they grabbed us." He is the only one who survived.

This sequence of events illustrates the schism that Mr. P. uses to avoid coming face to face with his traumatic experiences. At the same time, it is apparent that he is unable to understand his current situation (non-Jewish wife and childlessness) in the context of his persecution experiences.

Mr. A. is also a concentration camp survivor. He suffers from very poor health. During one conversation, he describes how he managed to save his very ill father from a seemingly hopeless persecution situation. In retrospect, he said, he is almost unable to understand how that came about. Without his father, he "simply could not have lived". Today, he wants to die. He does not want to suffer anymore.-- "But my children do not allow it."

This is a remarkable example of non-verbal communication between Mr. A. and his children. He delegates to them what was his own duty 
towards his father: to save his life. It is a "life alliance" that cannot be "terminated". The extent of holding on to it corresponds to the extent of suffering and the violent destruction that is hidden behind these seemingly innocuous words. Mr. A. must not want to die.

Concentration camp survivor Mrs. R. described to me in a mixture of German and Yiddish and in a state of extreme tension, one of the most terrible things I had ever been told personally. The woman talked about the selection of her family, about how she, pretending to be sixteen, stayed alive while her family members, parents, brothers and sisters, "went into the gas". One night, someone gave her "a bundle", a new-born child, and she was told to drown the infant in the latrine bucket. Unable to do this, she ran about in despair, frightened someone would see her with the child. She wanted to kill herself, "walk into the fence", "do something". In the end, she passed "the bundle" on to someone else, knowing that others would do what she could not. Ever since then, she has been living with the most severe feelings of guilt: "But what else could I have done?" She held on to me with one hand while waving her other arm. Soon however, she calmed down when she realized that I was not going to run away.

\section{SECOND GENERATION: MEMORY AND RECONSTRUCTION}

On the inside, I often did run away when survivors revealed to me their memory fragments. These were often almost unbearable experiences. What I heard and felt often blended with my own fantasies, dreams and experiences. For example, my own children may suddenly appear to me as helpless victims of persecution. This helplessness, the feeling of being entirely at someone else's mercy, and the fears, contain elements of what can only be understood as a contamination through contact with survivors' encapsulated memories. Seeds of memory are transplanted, so to speak.

Only an analysis of these emotions, fantasies and countertransference reactions provides an inkling, can elucidate, what survivors consciously, and above all unconsciously, try to communicate to us. Not until dissociated fragments of persecution experiences have been merged, is it possible to truly recognize the horror, the suffering and the consequences of extreme traumatization. Not even the very significant and moving experiences of survivors can, on their own, fully reconstruct the horrors that were suffered. Experiences of systematic genocide far exceed human capacity for comprehension; it is not possible to represent the extent of the horror while it is happening, nor is it possible to do so in retrospect and individually. These experiences of persecution-as described above-cannot be 
integrated; they are expressed collectively as a social process and, in particular, intergenerationally. Survivors communicate them above all unconsciously and non-verbally. The descendants of the victims take in something that shapes their own perception, their emotions and their thinking. The trauma of the First Generation thus becomes an integral part of the life of the Second Generation. Experiencing this connection represents an enormous challenge for both generations (cf. Grünberg, 1997, 2004).

\section{LOVE AFTER AUSCHWITZ}

A relatively large proportion of the descendants of Jewish survivors in Germany that I interviewed (Grünberg, 2000, 2006a) was childless. This particularly applies to relationships with non-Jewish-German partners. Only eight of the 20 Jewish interviewees had a non-Jewish partner at the time of the interviews. A few lived with their non-Jewish partners. Mostly, those whose partners were also Jewish had children. Even though not statistically significant, these findings may give you an idea about the deeply rooted insecurities that are felt by Second Generation Jews in Germany about the possibility of having a long-term and stable future in that country.

Forty-year-old Rachel G. ${ }^{2}$ a freelance photographer, is single and lives on her own. At the time of the study, she had a German boyfriend, Rudolf. Her survivor parents originally came from Czechoslovakia. Rachel is distressed and talks about a miscarriage she had only a few weeks prior to our meeting. Initially, during the interview, which lasted several hours, she expressed her tolerance towards her non-Jewish German environment. Suddenly, however, she announces that she wants to bring up a child by her partner on her own and perhaps leave Germany. She suddenly says with emphasis that Rudolf is not Jewish. While she stresses that he is not "the typical German", his family had opposed National Socialism, and she could nonetheless not help seeing him as German: "Having a child by a German", was something she could definitely not have done to her parents. Bearing in mind her recent miscarriage, this part of the interview culminated in her saying that were her parents still alive, she would have "got rid of" the child. Towards the end of the interview, we talk about Rachel's brother, who also doesn't have any children. She concludes, in a resigned way:

And so I assume our family dies out when we die.-Well, I don't know how else to look at it. That we went as far as that. Well, that we, unconsciously or consciously went as far as that, that this name will eventually die out.

Here, Rachel mentions something very significant: the foreseeable extinction of her family. After the murder of her ancestors by the Nazis, she now 
imagines that her as well as her brother's childlessness means that her father's name ${ }^{3}$ is being extinguished once and for all. ${ }^{4}$ It signifies the breakoff of the lineage of her family and thus the end, quite literally; an end that goes beyond an individual's death. Rachel, who remained unmarried and kept her father's name, thus speaks about a late "victory of Hitler" over her own family.

It can be assumed that Rachel unconsciously reproaches her parents for not having protected her from the poisonous introject of the Nazis-a fantasy that can only be "fulfilled" at the price of childlessness. Her relationship with a non-Jewish German man can be viewed as a desperate attempt of restitution, which she almost maniacally uses to stave off her fear of annihilation; it will not happen again: the attempt to start anew.

In many interviews, I encountered a desperate reproach of the Second Generation towards survivor parents: why Germany of all places? A relationship with a non-Jewish German thus necessarily means getting involved with a representative of the persecutors: is that the "normal state" of German-Jewish relationships in Germany after the Shoah?

\section{GERMANS AND JEWS}

In public discourse, the life of perpetrators and of victims of NS persecution are often positioned side by side, as if there was a mode through which they could be compared. There are, however, no such parallels (Grünberg, 2001, 2006b). As described above, the surviving victims suffer from the wrong that was done to them for decades afterwards. The perpetrators, on the other hand, usually grew or grow old in peace in Germany, because, amazingly, they are able to live with what they did and have peace. In certain contexts, they proudly say that they had the "strength" to carry out the "difficult task" posed to them "with decency". ${ }^{5}$ Who has not heard people say about a Jewish person that they "forgot to gas him"? ${ }^{6}$ Imagine just for a moment that Germany had won the war: would there not be thousands of awards for the "heroic commitment to defend the Arian blood against the Jewish race in Europe" on as many ethnic German collars? Rachel was shocked when she heard how an old man boasted that he unfortunately "only" murdered "one" Jew (Grünberg, 2006a, p. 147).

This illustrates another fundamental difference between victims and perpetrators, a difference that relates to the intergenerational transmission of parental experiences to their children. Among Jewish people, there is an uneasiness towards the German culture of majority, while non-Jewish Germans unconsciously pass on an anti-Semitic attitude, in the form of trivialization, final solution mentality and social coldness, all of which characterize the social climate. We could even say that the two sides pass 
on exactly what corresponds to the major NS experiences of the persons or groups of the time: victims pass on victimhood, perpetrators pass on perpetratorship to their descendants; Nazi sympathizers and bystanders unconsciously transmit those tendencies to their children. While the sons and daughters of Nazis are sometimes afraid that they do to their children what their parents did to them (Grünberg, 2004); the Jewish Second Generation is mostly afraid, like their parents, of not being able to protect their children from becoming victims. The fear of such a repetition shapes the German-Jewish relationship in Germany after the Shoah.

The question of individual characteristics implies the question of what the predominant culture is like. The attitude of "the society" determines the attitudes, statements and actions of individuals. Daniel Jonah Goldhagen's study (1996) was an attempt to discover to what extent "ordinary Germans" shared (and "support" to this day) the "eliminatory anti-Semitism" of the Nazi perpetrators. This touches upon the broad topic of guilt and responsibility (cf. Klein, 1992; Améry, 1980) as well as the complex issue of the "culture after Auschwitz" (Adorno, 1997b, p. 359).

I believe that it is not appropriate to psycho-pathologize individual perpetrators (in order to exonerate "ordinary Germans"), as if only "perverts, sadists or sick brains" are capable of committing such crimes. It would, however, be just as wrong to maintain that the Nazi perpetrators were not "sick," as if they had been "ordinary" everyday people (cf. Browning, 1992a, 1992b; Welzer, 2005) who are liable to attack at any opportunity (with the implication that ultimately everybody is innately predisposed to commit such inhumanities, if only a suitable occasion arises). The persecution of the Jews by the Nazis was "sick". It is a "socially conform sickness" that has become established via a "culture" that developed over centuries. Only this "culture" produced in the perpetrators the willingness to entertain such thoughts and to act (cf. Brainin, Ligeti, \& Teicher, 1993; Grunberger \& Dessuant, 2000), as it produced certain characteristics in the victims, which in turn appeared to justify the persecution. It was this set of conditions that "enabled" the systematic, industrial genocide as well as individual genocide of the Jewish people. In her analyses of NS perpetrators, Nele Reuleaux (2005) refers to the research on "malign narcissism". The notion of a "socially conforming psychopathy", which she developed, clarifies a number of issues.

Perpetrators only attracted attention once their deeds were discredited, which, unfortunately, happened very rarely. And so most Nazi criminals escaped punishment. This is not just fatal for the families of the victims, since the lack of punishment in a way stands for socially accepted acquittal. Survivors were confronted with the possibility of meeting former Nazis in the street at any time (which in fact did happen). At the same time, 
survivors suffer from what is called the "survivors' guilt" (Niederland, 1961), while most of the tormentors lived their life undisturbed. This is also of significance to the descendants of Nazi perpetrators, since their parents, at least apparently, hide their true involvement with the NS system and thus an important part of their history and identity. This is of some significance for the intergenerational transmission of an anti-Semitic attitude in the families of the perpetrators (cf. Grünberg, 2004).

A number of so-called "children of war" recently pointed to the traumas they themselves suffered. However, they most often limit their suffering to "the war". ${ }^{7}$ It is noticeable, for example, that the program of the international "Congress of the children of war," which took place in Frankfurt am Main on the occasion of the 60th anniversary of the end of the war, did not contain such terms as National Socialism, Nazi perpetrators and Nazi fathers. Instead, they talked about the war, about war fathers and about war men. That way, the relationship of the children of war to their parents' generation was supposed to be "kept pure of" National Socialism and hence the ideology that had caused this war. What this attitude denies is perpetratorship, participation by being a sympathizer and the resulting guilt of the parents. These parents subjected their own children to the perils of war from which they later suffered so terribly. After the fall of National Socialism, these same parents systematically lied to their children, denied what happened, distorted or glorified it. They concealed the truth in order to obscure their participation in the system of National Socialism. More than half a century after the end of the NS era, this is hardly ever talked about in Germany. This is an essential element of the trauma of the children of war.

This form of concealment was uncovered by Jean Améry many decades before the children-of-war debate. Addressing the 'children of war' and the 'post-war children', he said: "It is not your concern what happened, because you didn't know or were too young or you were not even born at the time? You should have seen; your youth is no licence, and break with your father" (Améry, 1980). It may be superficially reassuring to refuse to deal with this, in order to live in apparent peace with oneself and with one's people. This certainly does not provide protection from the latent transmission of antiSemitism to the next generation. And once again, the opportunity of an authentic encounter between Germans and Jews after the Shoah is lost.

\section{NOTES}

1. This caused US psychiatrist and psychoanalyst Kurt R. Eissler (1963), who worked as an expert adviser for victims of National Socialism, to ask the provocative question: "The murder of how many of his children can a human being endure without symptoms and still be normal?" 
2. The detailed case study can be found in Grünberg (2006a).

3. According to Jewish tradition, a person is Jewish if his or her mother is Jewish; naming, however, follows the father's lineage.

4. In the bible, the extinction of a name is one of the most terrible curses; for example, with regard to Amalek, the persecutor of the Jews, it is demanded that his name be extinguished.

5. In this context, I would like to remind the reader about the revealing speech by "Reichsführer SS" Heinrich Himmler, which he gave on 4th October 1943 at an SS group leader conference in Posen. He spoke of "a 'very difficult chapter' about which the SS must never talk about in public - 'the evacuation of the Jews, the extermination of the Jewish people'. One should talk about it now [...]. It is easy, he said, to include such notions as 'elimination of Jews' or 'extermination of Jews' in the NS programme, it is a different matter altogether, he said, to implement this programme. In principle, Himmler said sarcastically, Germans support the persecution; but anybody could come along and try to save the one 'decent' Jew that he knows. Of all those who behaved that way, none of them know, he continues, what it means to have 100 or 500 or 1000 dead bodies lying there. Himmler boasted that the SS managed to persevere and that-'apart from exceptions of human weakness' - they remained decent. This is, Himmler says, 'a glorious chapter of our history that has never been written and will never be written' [...]. 'We had a moral right, we had an obligation towards our people, to kill this people that wanted to kill us' [...]. 'We do not have the right to enrich ourselves, even if it is just one fur coat, one Mark or one cigarette'. That was the most piercing and most emotional sentence in the entire speech. The architect of mass murder considered himself to be a moralist until the bitter end" (quoted from Breitman, 1991, p. 319 et seqq.; transl. by N.R., emphasis, K.G.). There are regular conventions of Wehrmacht veterans in Germany to this day. For example, the annual Whitsun gathering of the former Wehrmacht mountain infantry in the Upper Bavarian Mittenwald. Despite the war crimes committed by the infantry, the massacres and their participation in deportations, this so-called tradition is politically tolerated and even promoted. Minister president and former Chancellor candidate of the CDU/CSU parties, Edmund Stoiber, supports the mountain infantry through his membership in the "Kameradenkreis" (circle of comrades). Never mind the likes of Kiesinger, Globke and Filbinger, who received support from West German post-war society despite knowing (or because they knew?) about their NS past. That way, Nazi crimes were made respectable.

6. In his controversial play Der Müll, die Stadt und der Tod (The Garbage, the City, and Death), one of playwright Rainer Werner Fassbinder's characters, Hans von Gluck, says about "The Rich Jew" (the only person in the play with no name): "They forgot to gas him" (1981, p. 88). Thus, Fassbinder put on stage what ordinary people would often say among friends, what neo-Nazis state openly.

7. This is equally true of the much-praised film "Der Untergang" by film producer Bernd Eichinger (Constantin Film, 2004).

\section{REFERENCES}

Adorno, T.W. (1997a). Kulturkritik und Gesellschaft. In Gesammelte Schriften, vol. 10-1. (pp. 11-30) Frankfurt a.M.: Suhrkamp, (Original work published 1951).

Adorno, T.W. (1997b). Negative Dialektik. In Gesammelte Schriften, vol. 6 (pp. 7-412) Frankfurt a.M.: Suhrkamp, (Original work published 1966). 
Améry, J. (1980). Jenseits von Schuld und Sühne. Bewältigungsversuche eines Überwältigten. Stuttgart: Klett, (Original work published 1966).

Brainin, E., Ligeti, V. \& Teicher, S. (1993). Vom Gedanken zur Tat. Zur Psychoanalyse des Antisemitismus. Frankfurt a.M.: Brandes \& Apsel.

Breitman, R. (1991). The architect of genocide. Himmler and the final solution. New York: Knopf. (Quoted from: Der Architekt der "Endlösung". Himmler und die Vernichtung der europäischen Juden. Paderborn: Schöningh, 1996).

Browning, C.R. (1992a). Ordinary men. Reserve Police Battalion 101 and the final solution in Poland. New York: Aaron Asher Books.

Browning, C.R. (1992b). The path to genocide. Essays on launching the final solution. Cambridge: Cambridge University Press.

Bubis, I. (1993). Ich bin ein deutscher Staatsbürger jüdischen Glaubens. Ein autobiographisches Gespräch mit Edith Kohn. Köln: Kiepenheuer und Witsch.

Bubis, I. (1999). Interview. Stern No. 31 of July 7, 1999, 56-59.

Cohen, R. (1998). Germany searches for normality. New York Times, November 29, 1998. Quoted from D. Hudson. A Branch in the Industry. URL: http://www. rewired.com/98/1214.html [June 23, 2006].

Edvardson, C. (1989). Die Welt zusammenfügen. München/Wien: Hanser.

Eickhoff, F.-W. (2004). Über die "unvermeidliche Kühnheit", "Erinnerungsspuren an das Erleben früherer Generationen" anzunehmen. Wie unentbehrlich ist der von Freud erschlossene phylogenetische Faktor? Psyche, 58, 448-457.

Eissler, K.R. (1963). Die Ermordung von wievielen seiner Kinder muss ein Mensch symptomfrei ertragen können, um eine normale Konstitution zu haben? Psyche, $17,241-291$.

Fassbinder, R.W. (1981). Der Müll, die Stadt und der Tod. In R.W. Fassbinder (Ed.), Die bitteren Tränen der Petra von Kant. Der Müll, die Stadt und der Tod. 2 Stücke. Frankfurt a.M.: Verlag der Autoren, 1984, p. 57-105.

Goldhagen, D.J. (1996). Hitler's willing executioners. New York: Knopf.

Grünberg, K. (1997). Schweigen und Ver-Schweigen. NS-Vergangenheit in Familien von Opfern und von Tätern oder Mitläufern. Psychosozial, 20(68), 9-22.

Grünberg, K. (2000). Zur Tradierung des Traumas der nationalsozialistischen Judenvernichtung. Psyche, 54, 1002-1037.

Grünberg, K. (2001). Vom Banalisieren des Traumas in Deutschland. Ein Bericht über die Tradierung des Traumas der nationalsozialistischen Judenvernichtung und über Strategien der Verleugnung und Rationalisierung der Shoah im Land der Täter. In K. Grünberg \& J. Straub (Eds.), Unverlierbare Zeit. Psychosoziale Spätfolgen des Nationalsozialismus bei Nachkommen von Opfern und Tätern (pp. 181-221) Tübingen: Edition diskord.

Grünberg, K. (2004). Erinnerung und Rekonstruktion. Tradierung des Traumas der nationalsozialistischen Judenvernichtung und Antisemitismus in der Bundesrepublik Deutschland. Trumah. Zeitschrift der Hochschule für Jüdische Studien Heidelberg, 14, 37-54.

Grünberg, K. (2006a). Love after Auschwitz-The Second Generation in Germany. Jewish children of survivors of the Nazi persecution in the Federal Republic of Germany and their experience with love relationships. Bielefeld: Transcript Verlag/New Jersey: Transaction Publishers. (Original work published in German 2000).

Grünberg, K. (2006b). On the myth of objective research after Auschwitz. Unconscious entanglements with the National Socialist past in the investigation of long-term psychosocial consequences of the Shoah in the Federal Republic of 
Germany. In K. Grünberg (Ed.), Love after Auschwitz-The Second Generation in Germany (pp. 283-302). Bielefeld: Transcript Verlag/New Jersey: Transaction Publishers. (Original work published in German 2004).

Grunberger, B. \& Dessuant, P. (2000). Narzissmus, Christentum, Antisemitismus. Eine psychoanalytische Untersuchung. Stuttgart: Klett-Cotta. (Original work published 1997).

Hadar, Y. (1991). Existentielle Erfahrung oder Krankheitssyndrom? Überlegungen zum Begriff der "Zweiten Generation". In H. Stoffels (Ed.), Schicksale der Verfolgten. Psychische und somatische Auswirkungen von Terrorherrschaft (pp. 160-172) Berlin/Heidelberg: Springer.

Kaminer, I. (2006). Tikun Haolam-Wiederherstellung der Welt nach der Shoah. Über Leben (sic!) nach der Shoah. In H. Kremp-Ottenheym, M. Juszczak \& M. Schmidt (Eds.), Heilung und Stagnation in psychoanalytischen Behandlungen. Arbeitstagung der DPV in Bad Homburg, 16. bis 19. November 2005 (pp. 15-39) Bad Homburg: Geber \& Reusch.

Kertész, I. (1997). Kaddish for a child not born. Evanston: Hydra Books, (Quoted from: Kaddisch für ein nicht geborenes Kind. Reinbek bei Hamburg, 2002).

Klein, H. (1992). Von Schuld zu Verantwortung. Psyche, 46, 1177-1186.

Leuschner, W. (2004). Dissoziation, Traum, Reassoziation. In A. Eckhardt-Henn \& S.O. Hoffmann (Eds.), Dissoziative Bewusstseinsstörungen. Theorie, Symptomatik, Therapie (pp. 60-73) Stuttgart/New York: Schattauer.

Levi, P. (1988). The drowned and the saved. New York: Summit Books, (Quoted from: Die Untergegangenen und die Geretteten. München/Wien: Hanser, 1990).

Niederland, W.G. (1961). The problem of the survivor. Part I: Some remarks on the psychiatric evaluation of emotional disorders in survivors of Nazi persecution. Journal of the Hillside Hospital, 10, 233-247.

Reuleaux, N. (2005). Das Problem der Entdifferenzierung zwischen Opfern und Tätern des Nationalsozialismus im Konzept der intergenerativen Traumatransmission. Unpublished doctoral theses, Universität Hannover.

Schirrmacher, F. (1999). Die Walser-Bubis-Debatte. Eine Dokumentation. Frankfurt a.M.: Suhrkamp.

Welzer, H. (2005). Täter. Wie aus ganz normalen Menschen Massenmörder werden. Frankfurt a.M.: Suhrkamp. 